\title{
Pengaruh Motivasi Belajar, Lingkungan Sosial, dan Sikap Belajar Terhadap Hasil Belajar Ekonomi di SMA/MA
}

\section{The Effect of Learning Motivation, Social Environment, and The Attitudes Learning On Outcomes of Economic In SMA/MA}

\author{
Sartina $^{a, 1}$, Setyabudi Indartono ${ }^{b, 2}$ \\ a SMAN 1 Dampal Selatan Tolitoli, ${ }^{\mathrm{b}}$ Universitas Negeri Yogyakarta \\ ${ }^{1}$ maruftina1611@gmail.com, ${ }^{2}$ setyabudi_indartono@uny.ac.id
}

\begin{tabular}{l}
\hline Informasi artikel \\
\hline Kata Kunci: \\
motivasi belajar, \\
lingkungan tempat \\
tinggal, sikap belajar, dan \\
hasil belajar
\end{tabular}

ABSTRAK

Penelitian ini bertujuan untuk mengetahui pengaruh motivasi belajar, lingkungan sosial dan sikap belajar secara bersama-sama terhadap hasil belajar ekonomi di SMA/MA Dampal Tolitoli Provinsi Sulawesi Tengah. Penelitian ini merupakan penelitian ex-post facto dengan pendekatan kuantitatif. Populasi dalam penelitian ini adalah semua siswa kelas XII IPS. Sampel siswa sebanyak 159 dengan menggunakan teknik sampling jenuh. Hasil riset menunjukkan bahwa secara parsial maupun simultan motivasi belajar, lingkungan tempat tinggal, dan sikap belajar berpengaruh secara signifikan terhadap hasil belajar. Berdasarkan hasil yang diperoleh maka hipotesis pengaruh motivasi belajar, lingkungan sosial dan sikap belajar terhadap hasil belajar dapat diterima, sehingga dengan meningkatnya motivasi belajar, lingkungan sosial yang kondusif dan sikap belajar yang positif maka akan semakin meningkatkan hasil belajar siswa.

\section{Keywords:}

motivation, learning environment where to stay, attitude of learning, and the learning outcomes

\section{ABSTRACT}

This research aims to know effect from the of learning motivation, social environment, attitudes on learning outcomes of Economics in SMA/MA Dampal Tolitoli Central Sulawesi Province. This research represent research of facto ex-post with quantitative approach. Population in this research all class student of XII IPS. Sampel Student counted 159 by using saturated sampling technique. The regression analysis results partially explain that as well as simultaneous learning motivation, social environment, learning to attitude effect significantly the results of the study. Pursuant to result of which obtained hence hypothesis effect of motivation learn, social environment and attitudes learning to result learn can be accepted, so that at the height of learning motivation, social environment which attitude and kondusif learn which are positive hence will progressively improve result learn student. 


\section{PENDAHULUAN}

Keberhasilan pendidikan dapat dilihat dari peningkatan kualitas sumber daya manusia (SDM). SDM yang berkualitas akan mampu mengembangkan potensi yang dimiliki untuk kemajuan bangsa dan negara. Salah satu upaya membina dan membangun SDM yang tangguh dan dapat diandalkan diantaranya adalah melalui pendidikan formal disekolah maupun pendidikan dilingkungan masyarakat.

Pendidikan merupakan ujung tombak pembangunan nasional, karena di dalamnya ada proses pembinaan untuk menciptakan sumber daya manusia (SDM) yang handal dan berkualitas. Pada saat ini keunggulan suatu bangsa tidak lagi ditandai dengan melimpahnya kekayaan alam, melainkan pada keunggulan Sumber Daya Manusia (SDM).

Pendidikan merupakan salah satu sarana strategis bagi peningkatan mutu sumber daya manusia, selain itu pendidikan juga merupakan salah satu tolok ukur tingkat kemajuan suatu bangsa. Atas dasar itu pula, upaya untuk meningkatkan kualitas penyelenggaraan pendidikan akan senantiasa dilakukan.

Pendidikan dianggap sebagai alternatif yang bersifat preventif karena pendidikan membangun generasi baru bangsa yang lebih baik. Pendidikan diharapkan dapat mengembangkan kualitas generasi muda bangsa dalam berbagai aspek yang dapat memperkecil dan mengurangi penyebab berbagai masalah budaya dan karakter bangsa.

Kabupaten Tolitoli khususnya di Kecamatan Dampal menunjukkan data tahun 2015 bahwa sebanyak $15,6 \%$ penduduknya belum pernah sekolah, $24,6 \%$ belum tamat SD, $37,11 \%$ tamat SD, $13,8 \%$ tamat SMP, $7,08 \%$ tamat SMA, dan hanya $0,54 \%$ lulusan dari akademi maupun perguruan tinggi.

Sampai saat ini di Kecamatan Dampal, hanya terdapat 4 Sekolah Menengah Atas yang tersebar di dua kecamatan yaitu Kecamatan Dampal Selatan dan Kecamatan Dampal Utara. Seharusnya hal ini, menjadi perhatian pemerintah kabupaten Tolitoli khususnya pemerintah Kecamatan Dampal, dalam hal untuk memyediakan sarana dan prasarana pendidikan, dan memberikan sosialisasi akan pentingnya pendidikan kepada masyarakat di Kecamatan Dampal, sehingga masyarakat didaerah tersebut menyadari bahwa pentingnya meningkatkan pendidikan.
Berdasarkan data hasil ujian akhir nasional dari tahun pelajaran 2011/2012 sampai dengan tahun pelajaran 2014/2015, yang menjadi problematika adalah masih rendahnya hasil belajar yang dicapai oleh siswa, khususnya hasil belajar mata pelajaran ekonomi siswa SMA/MA di Dampal yang disajikan pada tabel di bawah ini:

Tabel 1. Rata-Rata Hasil UAN SMA/MA

Dampal Mata Pelajaran Ekonomi Tahun Pelajaran 2011-2015

\begin{tabular}{|c|c|c|c|}
\hline $\begin{array}{c}\text { SMAN } \\
1 \\
\text { Dampal } \\
\text { Selatan } \\
\end{array}$ & $\begin{array}{c}\text { SMAN } \\
1 \\
\text { Dampal } \\
\text { Utara } \\
\end{array}$ & $\begin{array}{l}\text { Madrasah } \\
\text { Aliyah } \\
\text { DDI } \\
\text { Bangkir }\end{array}$ & $\begin{array}{l}\text { Madrasah } \\
\text { Aliyah } \\
\text { DDI Soni }\end{array}$ \\
\hline 50,48 & 60,37 & 52,50 & 47,70 \\
\hline 40,17 & 40,30 & 37,50 & 40,77 \\
\hline 38,81 & 60,00 & 33,00 & 37,60 \\
\hline 34,49 & 72,63 & 40,60 & 48,32 \\
\hline
\end{tabular}

Data hasil ujian nasional tahun 2011 sampai tahun 2015 menunjukkan bahwa nilai rata-rata siswa pada mata pelajaran ekonomi di sekolah tersebut relatif masih rendah dan telah terjadi fluktuasi mulai tahun pelajaran 2011/2012 sampai tahun pelajaran 2014/2015, bahkan salah satu sekolah negeri yaitu SMAN Dampal Selatan mengalami penurunan nilai rata-rata dari tahun ke tahun. Oleh sebab itu, hal inilah yang menjadi permasalahan dengan rendahnya nilai tersebut.

Salah satu penyebab rendahnya hasil belajar pada mata pelajaran ekonomi adalah proses pembelajaran belum efektif. Proses pembelajaran masih terlalu berorientasi terhadap penguasaan teori dan hafalan yang menyebabkan kemampuan belajar siswa menjadi terhambat. Selain itu metode pembelajaran terlalu berorientasi pada guru, yang mengabaikan hak-hak dan perkembangan siswa sehingga proses pembelajaran menjadi kurang optimal.

Berdasarkan hasil observasi awal, ditemukan bahwa beberapa hal yang mempengaruhi hasil belajar atau nilai siswa adalah rendahnya motivasi belajar, kurangnya perhatian dan dorongan dari keluarga atau orang tua, lingkungan sosial yang tidak kondusif dalam melakukan proses belajar, dan sikap belajar siswa yang negatif terhadap proses pembelajaran yang dilakukan. 
Tulisan ini akan menyajikan gagasan dan analisis penulis tentang bagaimana Pengaruh Motivasi Belajar, Lingkungan Sosial, dan Sikap Belajar terhadap Hasil Belajar Mata Pelajaran Ekonomi Siswa di SMA/MA Dampal Tolitoli Provinsi Sulawesi Tengah. Artikel ini ditulis khususnya dalam konteks kajian pendidikan di Indonesia.

\section{Hasil Belajar}

Simanjuntak (2013, p. 95), mengatakan bahwa hasil belajar merupakan hal yang sangat penting untuk di kaji, sebab hasil belajar merupakan salah satu indikator kualitas pendidikan. Sedangkan menurut Ardiansyah (2006, p. 213) hasil belajar adalah kemampuankemampuan yang dimiliki oleh peserta didik setelah ia menerima pengalaman belajarnya. Dari pernyataan-pernyataan tersebut dapat disimpulkan bahwa hasil belajar adalah kemampuan yang dimiliki siswa dalam proses belajar mengajar.

Sudjana (2004) yang dikutip oleh Jihad \& Haris (2009, pp. 20-21) indikator hasil belajar yaitu : (a) Kriteria ditinjau dari sudut prosesnya menekankan kepada pengajaran sebagai suatu proses yang merupakan interaksi dinamis sehingga siswa sebagai subjek mampu mengembangkan potensinya melalui belajar sendiri. Untuk mengukur keberhasilan pengajaran dari sudut prosesnya dapat dikaji melalui beberapa persoalan seperti : (1) Apakah pengajaran direncanakan dan dipersiapkan terlebih dahulu oleh guru dengan melibatkan siswa secara sistematik; (2) Apakah kegiatan belajar siswa di motivasi guru sehingga ia melakukan kegiatan belajar dengan penuh kesabaran, kesungguhan dan tanpa paksaan untuk memperoleh tingkat penguasaan, pengetahuan, kemampuan serta sikap yang dikehendaki dari pengajaran itu; (3) Apakah memakai multi media; (4) Apakah siswa mempunyai kesempatan untuk mengontrol dan menilai sendiri hasil belajar yang dicapainya; (5) Apakah proses pengajaran melibatkan semua siswa dalam kelas; (6) Apakah suasana pengajaran atau proses belajar mengajar cukup menyenangkan dan merangsang siswa belajar; dan (7) Apakah kelas memiliki sarana belajar yang cukup lengkap, sehingga menjadi laboratorium belajar. (b) Kriteria ditinjau dari hasilnya. Di samping tinjauan dari segi proses, keberhasilan pengajaran dapat dilihat dari segi hasil. Berikut ini adalah beberapa persoalan yang perlu dipertimbangkan dalam menentukan keberhasilan pengajaran ditinjau dari segi hasil atau produk yang dicapai siswa: (1) Apakah hasil belajar yang diperoleh siswa dari proses pengajaran nampak dalam bentuk perubahan tingkah laku secara menyeluruh; (2) Apakah hasil belajar yang dicapai siswa dari proses pengajaran dapat diaplikasikan dalam kehidupan siswa; (3) Apakah hasil belajar yang diperoleh siswa tahan lama diingat dan mengendap dalam pikirannya, serts cukup mempengaruhi perilaku dirinya; (4) Apakah yakin bahwa perubahan yang ditunjukkan oleh siswa merupakan akibat dari proses pengajaran.

\section{Motivasi Belajar}

Suyanto \& Jihad (2013, p. 60) motivasi berpangkal dari kata "motif". Biasanya motif diartikan sebagai daya penggerak yang ada dalam diri seseorang untuk melakukan aktivitas-aktivitas tertentu demi tercapainya suatu tujuan. Hal senada diungkapkan oleh Sardiman (2005, p. 73) bahwa motif merupakan daya penggerak dari dalam untuk melakukan kegiatan untuk mencapai tujuan.

Nguyen (2008, p. 1), mengatakan "Motivation is essential to learning since it is the driving force for students' to complete tasks that build knowledge". Motivasi penting bagi siswa dalam belajar karena merupakan kekuatan pendorong dalam menyelesaikan tugas-tugas dan memperoleh pengetahuan. Sedangkan Menurut Mulyasa (2008, p. 112) motivasi adalah tenaga pendorong atau penarik yang menyebabkan adanya tingkah laku ke arah suatu tujuan tertentu.

Brophy (2010, p. 3) mengutip pendapat Maehr \& Meyer mengatakan bahwa "Motivation is a theoretical construct used to explain the initiation, direction, intensity, persistence, and quality of behavior, especially goal-directed behavior". Motivasi merupakan suatu teori yang digunakan untuk membangun, menjelaskan arah, intensitas, ketekunan, dan mutu perilaku seseorang.

Berdasarkan beberapa pendapat diatas dapat disimpulkan bahwa motivasi belajar adalah keseluruhan daya penggerak didalam diri siswa yang menimbulkan kegiatan belajar menjamin kelangsungan dan memberikan arah pada kegiatan belajar sehingga tujuan yang dikehendaki dapat tercapai. Dalam motivasi belajar dorongan merupakan kekuatan mental untuk melakukan kegiatan dalam rangka pemenuhan harapan dan dorongan, dalam hal ini adalah pencapaian tujuan. 
Motivasi belajar dapat timbul karena faktor instrinsik, berupa hasrat dan keinginan berhasil dan dorongan kebutuhan belajar, harapan akan cita-cita. Sedangkan faktor ekstrinsiknya adalah adanya penghargaan, lingkungan belajar yang kondusif, dan kegiatan belajar yang menarik. Indikator motivasi belajar dapat diklasifikasikan menurut Uno (2008, p. 23), yaitu : (a) adanya hasrat dan keinginan berhasil, motif untuk berhasil dalam melakukan suatu tugas dan pekerjaan atau motif untuk memperoleh kesempurnaan. Motif semacam ini merupakan unsur kepribadian dan prilaku manusia, sesuatu yang berasal dari "dalam" diri manusia yang bersangkutan. Motif berprestasi adalah motif yang dapat di pelajari, sehingga motif itu dapat diperbaiki dan dikembangkan melalui proses belajar. Seseorang yang mempunyai motif berprestasi tinggi cenderung untuk berusaha menyelesaikan tugasnya secara tuntas, tanpa menunda-nunda pekerjaanya. Penyelesaiaan tugas semacam ini bukanlah karena dorongan dari luar diri, melainkan upaya pribadi; (b) adanya dorongan dan kebutuhan dalam belajar, Penyelesaian suatu tugas tidak selamanya dilatarbelakangi oleh motif berprestasi atau keinginan untuk berhasil, kadangkala seorang individu menyelesaikan suatu pekerjaan sebaik orang yang memiliki motif berprestasi tinggi, justru karena dorongan menghindari kegagalan yang bersumber pada ketakutan akan kegagalan itu. Seorang siswa mungkin tampak bekerja dengan tekun karena kalau tidak dapat menyelesaikan tugasnya dengan baik maka dia akan malu pada gurunya, atau di olok-olok temannya, atau bahkan dihukum oleh orang tua; (c) adanya harapan dan cita-cita masa depan, Harapan didasari pada keyakinan bahwa orang dipengaruhi oleh perasaan mereka tentang gambaran hasil tindakan mereka contohnya orang yang menginginkan kenaikan pangkat akan menunjukkan kinerja yang baik kalau mereka menganggap kinerja yang tinggi diakui dan dihargai dengan kenaikan pangkat. Pernyataan verbal atau penghargaan dalam bentuk lainnya terhadap perilaku yang baik atau hasil belajar siswa yang baik merupakan cara paling mudah dan efektif untuk meningkatkan motivasi belajar siswa terhadap hasil belajar yang lebih baik; (d) adanya penghargaan dalam belajar, Pernyataan seperti "bagus", "hebat" dan lainlain disamping akan menyenangkan siswa, pernyataan verbal seperti itu juga mengandung makna interaksi dan pengalaman pribadi yang langsung antara siswa dan guru, dan penyampaian konkret, sehingga merupakan suatu persetujuan pengakuan sosial. Apalagi kalau penghargaan verbal itu diberikan didepan orang banyak; (e) adanya kegiatan yang menarik dalam belajar, Suasana yang menarik menyebabkan proses belajar menjadi bermakna. Sesuatu yang bermakna akan selalu diingat, dipahami, dan dihargai. Seperti kegiatan belajar seperti diskusi, brainstorming, pengabdian masyarakat dan sebagainya; (f) adanya lingkungan belajar yang kondusif sehingga memungkinkan peserta didik dapat belajar dengan baik. Umumnya motif dasar yang bersifat pribadi muncul dalam tindakan individu setelah dibentuk oleh lingkungan. Oleh karena itu motif individu untuk melakukan sesuatu misalnya untuk belajar dengan baik, dapat dikembangkan, diperbaiki, atau diubah melalui belajar dan latihan, dengan perkataan lain melalui pengaruh lingkungan belajar yang kondusif salah satu faktor pendorong belajar siswa, dengan demikian siswa mampu memperoleh bantuan yang tepat dalam mengatasi kesulitan atau masalah dalam belajar.

Motivasi belajar mata pelajaran ekonomi siswa di SMA/MA di Dampal, khususnya kelas XII IPS masih rendah, hal ini diindikasikan bahwa masih ada siswa yang menghindar saat pelajaran ekonomi, ada pula siswa saat pembelajaran berlangsung lebih banyak bercerita dan mengerjakan hal lain dibandingkan memperhatikan penjelasan guru.

Berdasarkan hal tersebut di atas, Lin \& Jou (2013, p.157), menyatakan "enhancing student learning motivation is important for the teaching and learning of new knowledge or skills because motivation would affect how instructors and students interact with learning materials". Meningkatkan motivasi belajar siswa adalah penting untuk proses pembelajaran karena motivasi akan mempengaruhi bagaimana guru dan siswa berinteraksi dengan materi pembelajaran. Oleh karena itu, untuk meningkatkan kulitas pembelajaran, guru harus dapat memotivasi siswa agar lebih giat belajar.

Motivasi belajar sangat penting peranannya bagi siswa dalam usaha mencapai hasil belajar yang tinggi. Siswa yang memiliki motivasi belajar yang tinggi, cenderung menunjukkan semangat dan kegairahan dalam mengikuti pembelajaran, mereka biasanya kelihatan lebih menaruh perhatian bersungguhsungguh dalam belajar dan aktif berpartisipasi 
dalam kegiatan pembelajaran, baik di kelas maupun di luar kelas.

Siswa yang memiliki motivasi belajar ekonomi yang tinggi akan lebih tekun, bersemangat, lebih tahan dan memiliki ambisi yang lebih tinggi dalam mencapai hasil belajar yang lebih baik, dibandingkan dengan siswa yang kurang atau tidak memiliki motivasi belajar. Mereka yang tidak memiliki motivasi belajar akan kelihatan kurang atau tidak bergairah dalam belajar maupun mengikuti pembelajaran di kelas, tidak menaruh perhatian terhadap pelajaran yang dipelajari, apatis dan tidak berpartisipasi aktif dalam belajar. Kondisi siswa yang kurang memiliki motivasi belajar sudah tentu tidak mampu menghasilkan hasil yang memuaskan.

Penelitian yang dilakukan oleh Schober $\&$ Keller (2012), yang berjudul "Impact factors for learner motivation in Blended Learning environments". Menunjukkan bahwa efek positif pada motivasi siswa, dalam sebuah studi dua tahun oleh Institut Geografi Universitas Innsbruck, 176 murid berusia antara 15 dan 19 tahun dari empat sekolah di empat negara yang disurvei menunjukkan motivasi belajar berpengaruh terhadap hasil yang dicapai.

Dalam kaitannya dengan materi pelajaran ekonomi, selama ini siswa cenderung tidak memiliki keinginan untuk mempelajarinya. Hal ini tidak terlepas dari kurangnya motivasi yang diberikan oleh pengajar dalam proses belajar mengajar. Berdasarkan kerangka berpikir tersebut di atas, maka dapat diindikasi adanya pengaruh antara motivasi belajar dengan hasil belajar ekonomi siswa, karena motivasi belajar berperan penting dalam setiap pencapaian tujuan siswa dalam proses pembelajaran.

\section{Hipotesis I}

Motivasi belajar berpengaruh positif terhadap hasil belajar ekonomi di SMA/MA Dampal Tolitoli Provinsi Sulawesi Tengah.

\section{Lingkungan Sosial}

Lingkungan sosial juga mempengaruhi hasil belajar siswa. Lingkungan dalam pengertian umum, yaitu situasi di sekitar kita Ahmadi \& Uhbiyati (2003, p. 64). Sedangkan menurut Yusuf \& Sugandhi (2011, p. 23) Lingkungan adalah keseluruhan fenomena (peristiwa, situasi, atau kondisi) fisik/alam atau sosial yang mempengaruhi atau dipengaruhi perkembangan individu.
Lingkungan sosial budaya di luar lingkungan alami ternyata merupakan sisi kehidupan yang mendatangkan problem tersendiri bagi kehidupan siswa sekolah. Pembangunan gedung sekolah yang dekat dengan hiruk piruk lalu lintas menimbulkan kegaduhan suasana kelas. Pabrik-pabrik yang didirikan di sekitar sekolah dapat menimbulkan kebisingan di dalam kelas. Keramaian masih sayup-sayup terdengar oleh para siswa di dalam kelas. Bagaimana para siswa dapat berkosentrasi dengan baik bila berbagai gangguan selalu terjadi di sekitar mereka.

Menurut Purwanto (2011, p. 29) Lingkungan sosial adalah semua orang atau manusia lain yang dapat mempengaruhi manusia lain. Pengaruh lingkungan sosial itu ada yang diterima secara langsung dan ada yang tidak langsung. Pengaruh secara langsung seperti dalam pergaulan sehari-hari dengan orang lain, keluarga, teman-teman, kawan sekolah, sepekerjaan, dan lain sebagainya.Pengaruh yang tidak langsung yaitu: melalui radio, TV, majalah, buku-buku surat kabar dan lain sebagainya. Coleman (2013, pp. 4-5), mengatakan bahwa: "This theory begins with the principle that families interact with but are separate from other social systems such as schools, religious institutions, and youth groups. As children move among these social systems they are exposed to different experiences and points of view that contribute to their development and education".

Teori prinsip keluarga itu saling berhubungan dengan sistem sosial seperti sekolah, institusi religius, dan kelompok pemuda, ketika anak-anak berada pada suatu keadaan, mereka menunjukkan pengalaman yang berbeda-beda sehingga sistem sosial dapat berperan untuk pendidikan dan pengembangan mereka. Manusia tinggal dilingkungan yang berbeda-beda, tentunya lingkungan sekitar dapat mempengaruhi perkembangan hidup seseorang. Lingkungan mempengaruhi perkembangan individu. Lingkungan banyak memberikan pengalaman kepada individu. Pengalaman yang diperoleh oleh individu ikut mempengaruhi hal belajar yang bersangkutan.

Berns (2004, p. 44) mengatakan bahwa " the Family is the child's introduction to society and, therefore, bears the major responsibility for socializing the child. The family into which a child is born places the child in a community and in a society; newborns begin their social lives by acquiring 
the status their families have, which influences their opportunities". Keluarga yang bertanggung jawab mengenalkan anak kepada masyarakat, karena anak dilahirkan di dalam suatu lingkungan masyarakat, dan memperoleh status dari dalam keluarganya. Dan Grant \& Ray (2009, p.355) berpendapat bahwa "families can be encouraged to check out the information center before and after school or at other times if the school maintains a "drop in" policy with families welcome at any time". Untuk keberhasilan anak, keluarga dapat didukung dengan informasi yang diperoleh dari sekolah tentang kemajuan anak, sehingga keluarga dapat mengambil suatu kebijakan di setiap waktu dalam memfasilitasi anak dalam belajar.

Keberhasilan siswa bersosialisasi di lingkungannya menunjukkan keberhasilan dalam pembelajaran, berbagai masalah pembelajaran muncul karena begitu luasnya cakupan materi yang harus di kuasai oleh siswa. oleh karena itu guru harus mampu menanamkan konsep materi pelajaran agar lebih dipahami oleh siswa, sehingga pembelajaran dapat terlaksana dengan baik, dan siswa mampu beradaptasi dengan baik di lingkungannya ( Hendriani \& Aman, 2014 p. 108).

Dewantoro dalam Watoyo (2008, pp. 35-40) menggolongkan indikator lingkungan sosial siswa yaitu : (1) Lingkungan keluarga, terdiri dari : (a) cara Mendidik Anak; (b) hubungan antara anggota keluarga; (c) bimbingan dari orang tua; (d) suasana rumah; dan (e) keadaan ekonomi keluarga. (2) Lingkungan masyarakat terdiri dari : (a) teman bergaul; (b) lingkungan tetangga; (c) aktivitas dalam masyarakat; dan (d) mass media.

Siswa yang ada di SMA/MA di Dampal khususnya kelas XII IPS, sebagian besar hidup dan tinggal di lingkungan keluarga dan lingkungan sosial, dimana masyarakatnya memiliki tingkat pendidikan yang rendah dan tingkat kesadaran akan pentingnya pendidikan juga rendah. Dan juga Sebagian siswa yang lingkungan tempat tinggalnya jauh dari fasilitas-fasilitas teknologi yang dapat mengakses materi-materi pembelajaran yang berfungsi untuk menunjang pengetahuan siswa dalam meningkatkan hasil belajar khususnya mata pelajaran ekonomi.

Venkatesh Bala and Sanjeev Goyal (1998), Berdasarkan hasil penelitiannya mengungkapkan bahwa antara struktur lingkungan masyarakat berhubungan dengan proses pembelajaran sosial bagi siswa yang berdampak pada hasil belajar yang dicapai. Menurut Purwanto (2011, p. 28) lingkungan meliputi semua kondisi dalam dunia yang mempengaruhi tingkah laku kita, pertumbuhan, perkembangan manusia. Menurut Hamalik (2008, p. 98) mengungkapkan bahwa antara individu dan lingkungan terjalin proses interaksi atau saling mempengaruhi satu dengan lainnya.

Persoalan yang dihadapi remaja dalam keluarga, antara lain kurangnya perhatian orang tua dan kurang terpenuhinya kebutuhan hidupnya sehingga remaja mencari kegiatan diluar rumah yang tidak bermanfaat. Lingkungan sosial yang lebih banyak mempengaruhi kegiatan belajar adalah orang tua, keluarga, dan lingkungan tempat tinggal siswa itu sendiri.

Dengan demikian lingkungan sosial siswa di indikasikan mempunyai pengaruh signifikan terhadap hasil belajar siswa, karena lingkungan sosial akan berpengaruh bagi perkembangan kepribadian siswa. Selain itu, lingkungan juga merupakan hal yang sangat penting bagi siswa dalam memperoleh pendidikan dan proses adaptasi lingkungan.

\section{Hipotesis II}

Lingkungan sosial berpengaruh positif terhadap hasil belajar ekonomi di SMA/MA Dampal Tolitoli Provinsi Sulawesi Tengah.

\section{Sikap Belajar}

Menurut Bruno (1987), yang dikutip oleh Syah (2013, p. 5) mengatakan bahwa sikap (attitude) adalah kecenderungan yang relatif menetap untuk bereaksi dengan cara baik atau buruk terhadap orang atau barang tertentu. Sedangkan menurut Mulyana, dkk (2013, p. 19) Sikap merupakan salah satu istilah yang sering digunakan dalam mengkaji atau membahas tingkah laku manusia dalam kehidupan seharihari.

Sikap yang ada pada seseorang akan membawa warna dan corak pada tindakan, baik menerima maupun menolak dalam menanggapi sesuatu hal yang ada di luar dirinya. Melalui pengetahuan tentang sikap akan dapat menduga tindakan yang akan diambil seseorang terhadap sesuatu yang dihadapinya.

Menurut Suyanto \& Jihad, (2013, p. 228) sikap adalah sesuatu yang bermula dari perasaan (suka atau tidak suka) yang terkait dengan kecenderungan seseorang dalam 
merespon sesuatu atau objek. Senada dengan pendapat Kunandar (2014, p. 122) mengatakan bahwa Sikap merupakan suatu kecenderungan untuk bertindak secara suka atau tidak suka terhadap suatu objek. Lebih lanjut menurut Dahar (2011, p. 123) bahwa sikap merupakan pembawaan yang dapat dipelajari dan dapat mempengaruhi perilaku seseorang terhadap benda, kejadian-kejadian, atau mahluk hidup lainnya. Sekelompok sikap yang penting ialah sikap kita terhadap orang lain.

Berdasarkan definisi di atas dapat disimpulkan, sikap belajar adalah kecenderungan untuk bertindak berkenaan dengan proses pembelajaran, sikap bukan tindakan nyata (overtbehavior) melainkan masih bersifat tertutup (covertbehavior). Sikap belajar merupakan salah satu tipe karakteristik afektif yang sangat menentukan keberhasilan seseorang dalam proses pembelajaran. Dari semua pengertian yang di ungkapan di atas dapat diambil sebuah pengertian tentang sikap belajar adalah penilaian seseorang terhadap suatu obyek, situasi, konsep, orang lain maupun dirinya sendiri akibat hasil dari proses belajar maupun pengalaman di lapangan yang menyatakan rasa suka (respon positif) dan rasa tidak suka (respon negatif).

Widoyoko (2012, p. 241), mengungkapkan indikator sikap belajar siswa terdiri atas: (a) pemahaman manfaat pelajaran, dalam proses pembelajaran, pemahaman tentang manfaat suatu pelajaran harus lebih awal ditanamkan dalam diri siswa agar dalam menerima pelajaran benar-benar memahami manfaat dari apa yang di sampaikan; (b) rasa senang terhadap pelajaran, rasa senang atau kepedulian terhadap pelajaran itu sangat penting dalam proses pembelajaran. Perhatian terhadap peristiwa yang terjadi dalam proses pembelajaran, partisipasi siswa dan kenyamanan dalam proses pembelajaran harus terus ditingkatkan; dan (c) kecenderungan bertindak dalam pelajaran, suatu kondisi dalam proses pembelajaran yang tercipta dan terbentuk melalui serangkaian perilaku. Bertindak akan membuat siswa tahu dan dapat membedakan hal-hal apa yang harus dilakuakan, yang wajib dilakukan, yang boleh dilakukan, yang seharusnya dilakukan karena merupakan sesuatu yang dilarang.

Setiap siswa mempunyai sikap dan kebiasaan belajar sendiri-sendiri. Siswa yang mengikuti pelajaran ekonomi dengan sungguhsungguh, menyelesaikan tugas dengan baik, berpartisipasi aktif dalam diskusi, mengerjakan tugas-tugas rumah dengan tuntas dan selesai pada waktunya, dan merespon dengan baik tantangan yang datang dari pelajaran ekonomi. Hal ini menunjukkan bahwa siswa itu besikap positif pada pelajaran ekonomi, tetapi ada juga yang beranggapan atau merasa bahwa pelajaran ekonomi itu sulit untuk dimengerti, sehingga seringkali putus asa, mengabaikan atau tidak mengerjakan tugas dari pelajaran ekonomi yang tidak atau kurang disukai. Hal ini menunjukkan bahwa, siswa itu bersikap negatif pada pelajaran ekonomi. Sikap merupakan salah satu faktor yang mempengaruhi hasil belajar siswa.

Siswa yang ada di SMA/MA Dampal, khususnya kelas XII IPS, sikap siswa pada mata pelajaran ekonomi masih menunjukkan sikap yang negatif, hal ini diindikasikan bahwa masih ada siswa pada saat diberikan soal-soal ekonomi enggan berusaha menyelesaikan sendiri dan memilih untuk melihat pekerjaan teman sebangkunya, ada pula yang memprotes bila diberikan pekerjaan rumah oleh guru.

Penelitian yang dilakukan oleh The Fourth International Conference on Adult Education (2014), mengungkapkan bahwa sikap belajar berpengaruh terhadap hasil yang dicapai oleh responden siswa. Sikap juga sebagai ekspresi dari nilai-nilai pandangan hidup yang dimiliki oleh seseorang. Sikap dapat dibentuk, sehingga terjadi perilaku positif atau tindakan yang diinginkan.

Sikap yang diharapkan hendaknya sesuai dengan kemampuan siswa. Sasaran perilaku dan keberhasilan belajar hendaknya mudah dicapai. Semua ini sudah ditetapkan, sehingga siswa dapat merasakan sukses, pengakuan dan berbagai bentuk perhatian positif. Dimensi sikap yaitu arah, intensitas, keluwesan, konsisten, dan spontanitas. Hal ini menunjukkan bahwa sikap belajar merupakan salah satu faktor yang mempengaruhi hasil belajar siswa.

\section{Hipotesis III}

Sikap belajar berpengaruh positif terhadap hasil belajar ekonomi di SMA/MA Dampal Tolitoli Provinsi Sulawesi Tengah.

Tujuan dari proses pembelajaran disekolah adalah hasil belajar siswa yang baik, artinya salah satu indikator mutu sekolah yang baik jika hasil belajar siswanya baik. Prestasi belajar merupakan hubungan antara hasil 
belajar yang dilakukan siswa dengan tindak mengajar yang dilakukan oleh orang lain (misalnya guru). Pendidik terutama guru mempunyai strategi masing-masing agar siswa mendapatkan hasil belajar yang memuaskan, begitu juga siswa mempunyai strategi dalam belajar agar mereka dapat memahami suatu informasi sehingga prestasi yang dicapai dapat tinggi atau memenuhi target mereka.

Lingkungan merupakan bagian dari kehidupan para siswa. Siswa tidak bisa menghindarkan diri dari lingkungan alami dan lingkungan sosial budaya. Interaksi dari kedua lingkungan yang berbeda ini selalu terjadi dalam mengisi kehidupan siswa. Keluarga merupakan lingkungan pertama yang berpengaruh terhadap perkembangan anak, begitu juga teman dan lingkungan di sekitar tempat tinggal dapat mempengaruhi perkembangan anak. Pengaruh yang baik dari lingkungan akan mempengaruhi proses pembelajaran sehingga siswa akan termotivasi untuk melakukan hal-hal positif yang dapat bermanfaat dan meningkatkan prestasinya. Dalam proses pembelajaran siswa yang memiliki motivasi belajar yang tinggi akan bersikap positif di dalam menerima materi pembelajaran yang diberikan oleh orang lain, karena mereka menyadari bahwa merespon materi pelajaran dengan baik itu akan sangat bermanfaat dalam mengembangkan wawasan atau pengetahuan.

Siswa hidup dilingkungan yang mendukung proses pembelajaran, akan selalu termotivasi untuk melakukan hal-hal positif. Dalam proses pembelajaran, siswa yang memiliki motivasi belajar tinggi akan selalu berusaha mencapai yang terbaik. Siswa yang memiliki motivasi belajar yang tinggi akan selalu bersikap positif dalam proses pembelajaran, sikap ditunjukkan dalam mencapai tujuan dalam hal ini pencapaian hasil belajar yang tinggi.

\section{Hipotesis IV}

Motivasi belajar, Lingkungan sosial, dan sikap belajar secara bersama-sama berpengaruh positif terhadap hasil belajar ekonomi di SMA/MA Dampal Tolitoli Provinsi Sulawesi Tengah.

\section{METODE PENELITIAN}

Penelitian ini menggunakan pendekatan kuantitatif dengan jenis penelitian ex-post facto atau sering disebut dengan after the fact.
Artinya, penelitian yang dilakukan untuk melihat akibat yang terjadi, lalu dicari apa penyebabnya (Juliandi. dkk, 2014,p.14).

Penelitian ini di laksanakan di SMAN 1 Dampal Selatan, SMAN 1 Dampal Utara, Madarasah Aliyah DDI Bangkir, Madrasah Aliyah DDI Soni Dampal Tolitoli Sulawesi Tengah. Ke empat sekolah sekolah tersebut merupakan sekolah menengah atas yang terletak di dua kecamatan dikabupaten yaitu Kecamatan Dampal Selatan dan Kecamatan Dampal Utara. Penelitian ini dilaksanakan pada bulan Januari 2016.

Populasi yang juga merupakan sampel dalam penelitian ini adalah seluruh siswa kelas XII IPS SMA/MA yang ada di Dampal yang berjumlah 159 siswa. Teknik pengambilan sampel yang digunakan penulis dalam penelitian ini adalah Sampling Jenuh.

Tabel 2. Jumlah Siswa Sampel

\begin{tabular}{|c|c|c|c|}
\hline No & Sekolah & Kelas & $\begin{array}{l}\text { Jumlah } \\
\text { Siswa }\end{array}$ \\
\hline 1 & $\begin{array}{ll}\text { SMAN } & 1 \\
\text { Dampal } & \\
\text { Selatan } & \end{array}$ & $\begin{array}{l}\text { XII } \\
\text { IPS }\end{array}$ & 63 \\
\hline 2 & $\begin{array}{l}\text { SMAN } 1 \\
\text { Dampal Utara }\end{array}$ & $\begin{array}{l}\text { XII } \\
\text { IPS }\end{array}$ & 68 \\
\hline 3 & $\begin{array}{ll}\text { MA } & \text { DDI } \\
\text { Bangkir } & \end{array}$ & $\begin{array}{l}\text { XII } \\
\text { IPS }\end{array}$ & 16 \\
\hline 4 & MA DDI Soni & $\begin{array}{l}\text { XII } \\
\text { IPS }\end{array}$ & 12 \\
\hline & Jumlah & & 159 \\
\hline
\end{tabular}

Pengumpulan data menggunakan angket untuk variabel motivasi belajar, lingkungan sosial, dan sikap belajar serta dokumentasi untuk variabel hasil belajar.

Instrumen motivasi belajar siswa $\left(\mathrm{X}_{1}\right)$, diadopsi dari Nissa (2003), yang dijabarkan dalam 12 butir pernyataan, variabel lingkungan sosial $\left(\mathrm{X}_{2}\right)$, diadopsi dari Widoyoko (2012), dijabarkan dalam 10 butir pernyataan, dan instrumen Sikap Belajar Siswa $\left(\mathrm{X}_{3}\right)$, diadopsi dari Widoyoko (2012), dijabarkan dalam 9 butir pernyataan-pernyataan.

\section{HASIL PENELITIAN PEMBAHASAN}

Validitas dan Reliabilitas Instrumen

Menurut Wagiran (2014, p. 303), kriteria kelayakan instrumen maupun butir instrumen yaitu angka loading factor di atas 0,5 
Dalam penelitian ini variabel yang akan diukur validitasnya adalah variabel bebas yaitu motivasi belajar (X1), lingkungan sosial (X2), dan sikap belajar (X3), sedangkan variabel terikat yaitu hasil belajar (Y). Instrumen motivasi belajar siswa, lingkungan sosial, dan sikap belajar terdiri dari 12 butir pertanyaan/pernyataan. Sesuai dengan kriteria dari hasil perhitungan validitas uji coba semua pertanyaan/pernyataan valid. Hasil pengujian validitas item instrumen variabel ditunjukkan dalam tabel 3 .

Tabel 3. Faktor Loading untuk Item variabel

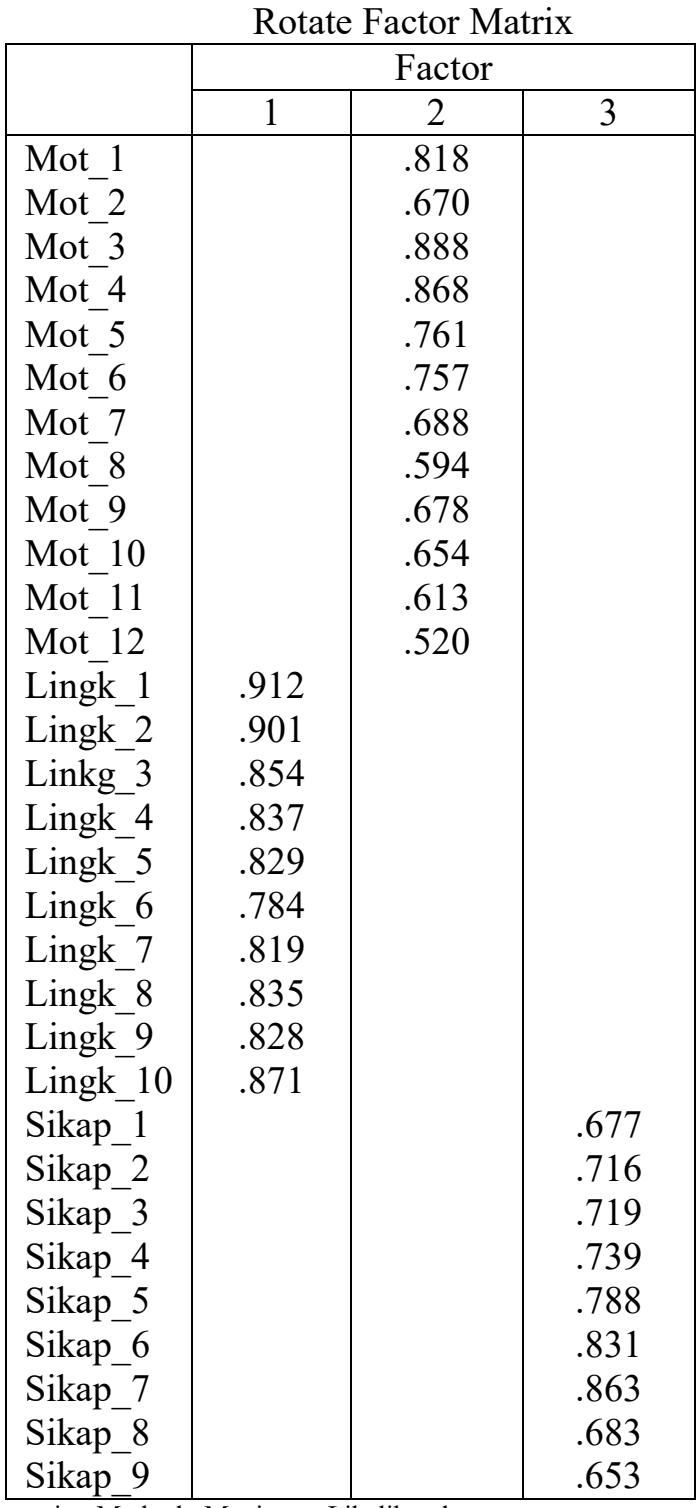

Exraction Method : Maximum Likelihood

Rotation Method: Varimax with Kaiser Normalization. ${ }^{\text {a }}$

a. Rotation convergen in 6 iterations.

Reliabilitas diukur dengan menggunakan Cronbach alpha. Cara menghitungnya dengan bantuan program SPSS. Suatu konstruk atau variabel dikatakan reliabel jika memberikan nilai alpha lebih besar dari 0,70 .

Hasil pengujian reliabilitas instrumen untuk: (a) variabel motivasi belajar siswa $\left(\mathrm{X}_{1}\right)$ diperoleh koefisien alpha sebesar 0,958; (b) variabel lingkungan sosial siswa diperoleh koefisien alpha sebesar 0,968; dan (c) variabel sikap belajar siswa $\left(\mathrm{X}_{3}\right)$ diperoleh koefisien alpha 0,972. Hal ini menunjukkan bahwa instrumen tersebut memiliki reliabilitas yang tinggi. Untuk itu, instrumen ini mempunyai kehandalan untuk mengukur variabel tersebut. Uji Hipotesis

Pengujian hipotesis dilakukan dengan menggunakan teknik analisis regresi. Sebagai kriteria penerimaan dan penolakan, dalam pengujian ini digunakan taraf signifikansi 5\%.

Tabel 4. Rangkuman Hasil Analisis Regresi

\begin{tabular}{|c|c|c|c|c|c|}
\hline & $\begin{array}{c}\text { Model } \\
1 \\
\end{array}$ & $\begin{array}{c}\text { Model } \\
2 \\
\end{array}$ & $\begin{array}{c}\text { Model } \\
3 \\
\end{array}$ & $\begin{array}{c}\text { Model } \\
4 \\
\end{array}$ & $\begin{array}{c}\text { Model } \\
5 \\
\end{array}$ \\
\hline Jender &,- 078 &,- 012 &,- 070 &,- 095 &,- 034 \\
\hline $\begin{array}{l}\text { T. Pend. } \\
\text { Ortu }\end{array}$ &,- 049 &,- 043 &,- 036 & ,005 &,- 007 \\
\hline $\begin{array}{l}\text { Asal } \\
\text { Sekolah }\end{array}$ &,- 076 &,- 024 &,- 097 &,- 023 &,- 010 \\
\hline $\begin{array}{l}\text { Motiv. } \\
\text { Belajar }\end{array}$ & &, $694^{* * *}$ & & &, $541^{* * *}$ \\
\hline $\begin{array}{l}\text { Ling. } \\
\text { Sosial }\end{array}$ & & &, $345^{* * *}$ & &, $112^{*}$ \\
\hline $\begin{array}{l}\text { Sikap } \\
\text { Belajar }\end{array}$ & & & &, $551^{* * *}$ &, $336^{* * *}$ \\
\hline $\mathrm{R}^{2}$ & ,015 & ,489 & ,134 & ,313 & ,605 \\
\hline$\Delta \mathrm{R}^{2}$ &, 015 &, $474^{* * *}$ &, $119^{* * *}$ &, $298^{* * *}$ &, $590^{* * *}$ \\
\hline$*$ & $<0,05$ & & & & \\
\hline$* *$ & $<0,01$ & & & & \\
\hline$* * *$ & $<0,001$ & & & & \\
\hline
\end{tabular}

Berdasarkan tabel di atas dapat diambil kesimpulan sebagai berikut : (a) variabel kontrol antara lain, jenis kelamin; tingkat pendidikan Orang tua; dan asal sekolah responden, tidak memberikan pengaruh secara positif terhadap variabel hasil belajar mata pelajaran ekonomi siswa SMA/MA; (b) nilai beta $(\beta)$ variabel motivasi belajar $\left(\mathrm{X}_{1}\right)$ adalah 0,694 dan signifikansi $<0,00$ sehingga dapat disimpulkan variabel motivasi belajar memberikan pengaruh secara positif terhadap hasil belajar siswa SMA/MA. Sumbangan efektif variabel motivasi belajar terhadap hasil belajar adalah $47,4 \%$ yang berarti bahwa $52,6 \%$ $(100 \%-47,4 \%)$ hasil belajar siswa ditentukan oleh faktor lain diluar variabel motivasi belajar tersebut; (c) nilai beta $(\beta)$ variabel lingkungan sosial $\left(\mathrm{X}_{2}\right)$ adalah 0,345 dan signifikansi $<0,00$ 
sehingga dapat disimpulkan variabel lingkungan sosial memberikan pengaruh secara positif terhadap hasil belajar siswa SMA/MA. Sumbangan efektif variabel lingkungan sosial terhadap hasil belajar adalah $11,9 \%$ yang berarti bahwa $88,1 \% \quad(100 \%-11,9 \%)$ hasil belajar siswa ditentukan oleh faktor lain diluar variabel lingkungan sosial tersebut; (d) nilai beta $(\beta)$ variabel sikap belajar $\left(X_{3}\right)$ adalah 0,551 dan signifikansi $<0,00$ sehingga dapat disimpulkan variabel sikap belajar memberikan pengaruh secara positif terhadap hasil belajar siswa SMA/MA. Sumbangan efektif variabel sikap belajar terhadap hasil belajar adalah $29,1 \%$ yang berarti bahwa 70,9\% (100\%$29,1 \%$ ) hasil belajar siswa ditentukan oleh faktor lain diluar variabel sikap belajar tersebut; (e) variabel motivasi belajar $\left(\mathrm{X}_{1}\right)$, lingkungan sosial $\left(\mathrm{X}_{2}\right)$ dan sikap belajar $\left(\mathrm{X}_{3}\right)$ di uji secara bersama-sama menghasilkan nilai beta masing-masing untuk variabel motivasi belajar sebesar 0,541 dengan signifikansi $<0,00$; lingkungan sosial nilai beta 0,112 dengan signifikansi $<0,05$; dan sikap belajar nilai beta 0,336 dengan signifikansi $<0,00$, sehingga dapat disimpulkan bahwa variabel motivasi belajar, lingkungan sosial, dan sikap belajar secara bersama-sama memberikan pengaruh secara positif terhadap hasil belajar mata pelajaran ekonomi siswa SMA/MA. Sumbangan efektif variabel motivasi belajar, lingkungan sosial dan sikap belajar terhadap hasil belajar adalah $59 \%$ yang berarti bahwa $41 \%(100 \%-59 \%)$ hasil belajar siswa ditentukan oleh faktor lain diluar variabel motivasi belajar, lingkungan sosial dan sikap belajar tersebut.

Berdasarkan uraian di atas, maka dapat disimpulkan bahwa terdapat pengaruh positif secara sendiri-sendiri maupun secara bersama-sama variabel motivasi belajar (X1), lingkungan sosial (X2), dan sikap belajar (X3) terhadap hasil belajar ekonomi siswa di SMA/MA Dampal Tolitoli Sulawesi Tengah (Y).

Pengaruh Motivasi Belajar terhadap Hasil Belajar Siswa

Berdasarkan hasil yang diperoleh maka hipotesis pengaruh motivasi belajar terhadap hasil belajar dapat diterima. Sehingga dengan meningkatnya motivasi belajar maka akan semakin meningkatkan hasil belajar siswa.

Secara umum, siswa di SMA/MA Dampal Tolitoli Sulawesi Tengah, yaitu SMA
Negeri 1 Dampal Selatan, SMA Negeri 1 Dampal Utara, MA DDI Soni, dan MA DDI Bangkir, mempunyai motivasi belajar yang cukup baik untuk mata pelajaran ekonomi. Motivasi belajar siswa tersebut merupakan kebutuhan para siswa untuk mempunyai hasil belajar dalam pembelajaran ekonomi melalui pencapaian nilai yang baik, penghargaan dari lingkungan baik orang tua, teman maupun guru.

Hasil penelitian ini mendukung teori McClelland (Jamaris, 2013, p. 172), yang dikenal teori kebutuhan untuk mencapai prestasi atau Need for Achievement (N.Ach) yang meyakini bahwa achievement dan motivasi mempunyai peranan yang sangat penting dalam kesuksesan individu mencapai tujuan yang telah ditetapkan. Menurutnya, motivasi belajar merupakan motivasi yang membuat individu berusaha mencapai hasil yang baik dari kegiatan yang dilakukannya dan berusaha mengatasi segala hambatan yang menghalangi usahanya untuk mencapai tujuan tersebut.

Pengaruh Lingkungan Sosial terhadap Hasil Belajar Siswa

Berdasarkan hasil yang diperoleh maka hipotesis pengaruh variabel lingkungan sosial terhadap hasil belajar dapat diterima. Sehingga dengan dapat dikatakan bahwa jika lingkungan sosial siswa baik dan mendukung maka akan semakin meningkatkan hasil belajar siswa.

Secara umum, siswa di SMA/MA Dampal Tolitoli Sulawesi Tengah, yaitu SMA Negeri 1 Dampal Selatan, SMA Negeri 1 Dampal Utara, MA DDI Soni, dan MA DDI Bangkir, mempunyai lingkungan sosial yang cukup baik. Lingkungan sosial yang kondusif akan mempengaruhi keberhasilan siswa, karena lingkungan yang mendukung kegiatan belajar siswa membuat siswa nyaman untuk dalam melakukan kegiatan belajarnya. Sehingga penghargaan dan dukungan dari keluarga dan masyarakat dimana siswa tersebut berada sangat penting dalam meningkatkan hasil belajar.

Hasil penelitian ini mendukung pendapat Hamalik (Jamali \& Prasojo, 2013, p. 1), mengatakan bahwa antara individu dan lingkungan terjalin proses interaksi atau saling mempengaruhi satu dengan lainnya. Lingkungan merupakan salah satu penyebab dari keberhasilan dalam melaksanakan tugas, apabila seorang siswa mendapat pengaruh positif , maka siswa tersebut akan mempunyai 
moral yang lebih baik dalam melakukan tugasnya, dan meningkatkan efisiensi dalam pencapaian suatu tujuan.

Pengaruh Sikap Belajar terhadap Hasil Belajar Siswa

Berdasarkan hasil yang diperoleh maka hipotesis pengaruh variabel sikap belajar terhadap hasil belajar dapat diterima. Sehingga dengan dapat dikatakan bahwa jika sikap belajar siswa positif atau baik maka akan semakin meningkatkan hasil belajar siswa

Secara umum, siswa di SMA/MA Dampal Tolitoli Sulawesi Tengah, yaitu SMA Negeri 1 Dampal Selatan, SMA Negeri 1 Dampal Utara, MA DDI Soni, dan MA DDI Bangkir, mempunyai sikap belajar yang cukup baik untuk mata pelajaran ekonomi. Sikap belajar siswa tersebut merupakan hal sangat penting demi keberhasilan siswa dalam mencapai tujuan. Sikap positif akan membawa siswa pada suatu tindakan yang positif pula, menerima dan menanggapi sesuatu hal yang positif dari luar dirinya. Sikap positif penting dalam proses pembelajaran karena sikap yang positif dapat menjadikan siswa paham dengan hal yang disampaikan oleh guru baik proses pembelajaran yang dilakukan di dalam kelas maupun di luar kelas.

Hasil penelitian ini mendukung penelitian sebelumnya yang dilakukan oleh Penelitian yang dilakukan oleh The Fourth International Conference on Adult Education, mengungkapkan bahwa sikap kepuasan belajar berpengaruh terhadap hasil yang dicapai oleh responden siswa.

Pengaruh Motivasi Belajar, Lingkungan Sosial dan Sikap Siswa terhadap Hasil Belajar

Hasil penelitian untuk uji simultan juga menunjukkan bahwa sumbangan efektif untuk variabel motivasi belajar terhadap hasil belajar sebesar 0,541 dengan taraf signifikansi < 0,001; lingkungan sosial terhadap hasil belajar sebesar 0,112 dengan taraf signifikansi $<0,05$; dan sikap belajar terhadap hasil belajar sebesar 0,336 dengan taraf signifikansi $<0,001$. Deskripsi data juga menunjukkan bahwa motivasi siswa memiliki kecenderungan relatif sedang sebesar $41,50 \%$. Dalam hal ini, hasrat dan keinginan berhasil, dorongan dan kebutuhan dalam belajar, harapan dan cita-cita masa depan, penghargaan dalam belajar, kegiatan yang menarik dalam belajar, lingkungan belajar yang kondusif di miliki oleh siswa di SMA/MA Dampal tinggi, sehingga motivasi belajar siswa dapat dikatakan sudah cukup baik di sekolah tersebut. Deskripsi data untuk variabel lingkungan sosial siswa memiliki kecenderungan relatif sedang sebesar $39 \%$, dalam hal ini dapat di simpulkan bahwa lingkungan siswa dalam melakukan proses belajar kondusif. Selanjutnya untuk variabel sikap belajar siswa berdasarkan deskripsi data memiliki kecenderungan sedang sebesar $43,40 \%$, dalam hal ini dapat disimpulkan bahwa sebagian besar siswa dalam proses pembelajaran memiliki sikap yang positif.

Namun kenyataannya, bahwa siswa yang memiliki hasil belajar yang rendah cukup banyak. Oleh karena itu, perlu mendapat perhatian serius dari semua pihak, baik dari siswa itu sendiri, kalangan orang tua, masyarakat, pendidikan maupun pemerintah. Hal ini sangat penting dalam rangka peningkatan hasil belajar siswa. untuk mendapatkan hasil belajar yang baik dan tinggi diperlukan pembinaan terhadap diri siswa, baik di dalam lingkungan sekolah maupun di luar lingkungan sekolah.

\section{KESIMPULAN}

Kesimpulan

Berdasarkan analisis data dan pembahasan hasil penelitian dapat disimpulkan bahwa : (1) ada pengaruh positif antara motivasi belajar terhadap hasil belajar mata pelajaran Ekonomi siswa di SMA/MA Dampal Tolitoli Provinsi Sulawesi Tengah; (2) ada pengaruh positif antara lingkungan tempat tinggal terhadap hasil belajar mata pelajaran Ekonomi siswa di SMA/MA Dampal Tolitoli Provinsi Sulawesi Tengah; (3) ada pengaruh positif antara sikap belajar siswa terhadap hasil belajar mata pelajaran Ekonomi siswa di SMA/MA belajar siswa dampal Tolitoli Provinsi Sulawesi Tengah; (4) ada pengaruh positif secara bersama-sama motivasi belajar, lingkungan tempat tinggal, dan sikap belajar siswa terhadap hasil belajar mata pelajaran Ekonomi siswa di SMA/MA Dampal Tolitoli Provinsi Sulawesi Tengah.

\section{Saran}

Berdasarkan hasil yang diperoleh dari penelitian yang dilakukan di Dampal Tolitoli, beberapa saran peneliti adalah : (1) para siswa diharapkan dapat meningkatkan motivasi belajar dengan karena cara meluangkan waktu 
untuk belajar dengan baik dan berusaha menyelesaikan tugas-tugas yang diberikan oleh guru, karena motivasi belajar merupakan salah satu faktor yang berpengaruh terhadap hasil belajar siswa Sekolah Menengah Atas dan Madrasah Aliyah terutama mata pelajaran Ekonomi; (2) orang tua meluangkan waktu, membimbing dan mengarahkan anaknya dalam belajar, serta memberikan kebebasan yang bertanggungjawab kepada anak seperti mengizinkan anak belajar bersama temanteman dengan melaporkan materi yang dipelajari kepada kedua orang tua; (3) guru diharapkan dapat membantu siswa tidak hanya dalam menyampaikan materi, akan tetapi dalam peningkatan motivasi belajar dan peningkatan sikap positif siswa dalam belajar dengan cara melakukan kompetisi, pujian atau memberikan hadiah kepada siswa dalam proses pembelajaran dengan tujuan agar siswa bergairah untuk belajar; (4) Sekolah diharapkan mensosialisasikan hasil penelitian ini kepada kedua orang tua siswa agar menjadi bahan pemikiran orang tua dalam meningkatkan hasil belajar siswa terutam Ekonomi, serta dapat merawat fasilitas-fasilitas yang sudah ada, seperti ruang kelas, dan lingkungan di luar ruangan guna menunjang proses pembelajaran; (5) Dinas Pendidikan lebih berupaya untuk memberikan fasilitas-fasilitas yang memadai sehingga dapat menunjang belajar siswa dan diharapkan hasil belajar siswa dapat meningkat; (6) kepada peneliti selanjutnya, diharapkan dapat memperluas wilayah penelitian dan menambah variabel lain diluar variabel penelitian yang sudah ada, yang memungkinkan dapat mempengaruhi hasil belajar.

\section{Daftar Pustaka}

Ahmadi, A \& Uhbiyati, N. (2003). Ilmu pendidikan.Jakarta: PT.Rineka Cipta.

Ardiansyah. (2006). Evaluasi dan penilaian belajar. Jakarta: Media Grup.

Badan Pusat Statistik Kabupaten Tolitoli. (2015). Profil Kabupaten Tolitoli. Propensi Sulawesi Tengah.
Bala, V., Goyal, S., (1998). Learning from Neighbours. Oxford Journals Social Sciences, 65, 3.

Berns, R.M. (2004). Child, family, school, community socialization and support sixth edition. California, Thomson Wadsworth.

Brophy, Jere. (2010). Motivating Students to Learn. New York and Landon : Michigan State University. Routledge Taylor \& Francis Group.

Coleman, M. (2013). Empowering familyteacher partnerships. Georgia, SAGE Publication, Inc.

Dahar, R.W. (2011). Teori-Teori Belajar \& Pembelajaran. Bandung : PT. Gelora Aksara Pratama.

Epstein, L. (2009). School, Family, and Community Partnerships. Thousand Oaks, California 91320. Corwin Press.

Grant, K. B., \& Ray, J. A. (2009). Home, school, and community collaboration. Missouri, Sage Publications, Inc.

Hamalik, Oemar. (2008). Proses belajar mengajar. Jakarta: PT. Bumi Aksara.

Hendriani \& Aman. (2014). Peningkatan Aktivitas dan Hasil Belajar IPS melalui implementasi Strategi Peta Konsep di SMP Muhammdiyah 3 Depok. Program Pascasarjana Universitas Negeri Yogyakarta, Harmoni Sosial Jurnal Pendidikan IPS, Volume 1,No.1,2014.

Jihad, A \& Haris, A. (2009). Evaluasi pembelajaran. Yogyakarta : Multi Pressindo.

Juliandi. (2014). Metodelogi Penelitian Bisnis Konsep Aplikasi.Medan: UMSU Press. 
Kunandar. (2014). Penilaian Autentik : Penilain hasil belajar peserta didik berdasarkan kurikulum 2013. Jakarta : PT. Rajagrafindo.

Mulyana, Aina \& Hidayat Soleh \& Sholih. (2013). Hubungan antara persepsi, minat, dan sikap siswa dengan hasil belajar siswa dalam pembelajaran $P K n$. Jurnal Pendidikan \& Kebudayaan. 19, 2.

Mulyasa. (2008). Guru profesional. Bandung: PT. Remaja Rosdakarya.

Nguyen Chi. (2008). Student motivation and learning. Journal of Humanities and Social Science, 2, 174.

Nissa, Hayatun. (2003). Prestasi belajar siswa SLTP negeri di Kecamatan Barabai. Tesis. Program Studi Pendidikan Teknologi dan Kejuruan. Universitas Negeri Yogyakarta.

Purwanto, Ngalim. (2011). Ilmu pendidikan teoretis dan praktis. Bandung : PT. Remaja Rosdakarya.

Sardiman, A.M. (2005). Interaksi dan motivasi belajar mengajar. Jakarta: PT Raja Grafindo Persada.

Scohober, Alexander \& Keller Lars. (2012). "Impact factors for learner motivation in Blended Learning environments" jurnal international. 7, 4 .

Simanjuntak, Hoholongan. (2013). Kontribusi kemampuan guru melaksanakan pembelajaran terhadap hasil belajar persamaan kuadrat pada siswa SMA Negeri 1 Pangkal Pinang. Jurnal Pendidikan \& Kebudayaan. 19, 191.

Suyanto \& Jihad, Asep. (2013). Menjadi Guru Profesional. Jakarta : Erlangga.
Syah, Muhibbin. (2013).Psikologi pendidikan dengan pendekatan baru. Bandung: PT. Remaja Rosdakarya.

The Fourth International Conference on Adult Education, Romania. (2014). "Attitudes towards Academic Learning and Learning Satisfaction in Adult Students". Oxford Journals Social Sciences. 65, 3.

Ting Lin, Yen., \& Min Jou. (2013). Integrating Popular Web Applications In Classroom Learning Environments And Its Effects On Teaching, Student Learning Motivation And Performance. The Turkish Online Journal of Educational Technology, 12,2 .

Uno, Hamzah B. (2008). Teori Motivasi \& Pengukurannya. Jakarta : Bumi Aksara.

Wagiran. (2014). Metodologi penelitian pendidikan.Yogyakarta : CV.Budi Utama.

Watoyo, Dwi. (2008). Hubungan antara lingkungan belajar dan minat belajar siswa dengan prestasi belajar siswa mata pelajaran akuntansi kelas XII Jurusan IPS SMA Negeri 1 Paninggaran Kabupaten Pekalongan. Tesis Magister. Universitas Sebelas Maret Surakarta. Surakarta.

Widoyoko, Eko, Putro. (2012). Teknik Penyusunan Instrumen Penelitian. Yogyakarta: Pustaka Pelajar.

Yusuf \& Sugandhi. (2011). Perkembangan peserta didik. Jakarta : PT. RajaGrafindo Persada. 


\section{Profil Singkat}

Sartina lahir pada 11 Nopember 1981 di Desa Bangkir, Kecamatan Dampal Selatan, Kabupaten Tolitoli, Provinsi Sulawesi Tengah. Riwayat pendidikan SDN 3 Bangkir (1987-1993), SLTPN 1 Bangkir (19931996), SMKN 1 Baolan Tolitoli (19961999), Universitas Negeri Manado Fakultas Ilmu Sosial Pendidikan Ekonomi Koperasi (2000-2004). Sebagai guru di SMAN 1 Dampal Selatan Kabupaten Tolitoli, dan sedang menempuh jenjang magister pada Program Studi Pendidikan Ekonomi Pasca Sarjana Universitas Negeri Yogyakarta.

\section{LAMPIRAN :}

\section{a. Instrumen Motivasi Belajar}

1. Setiap ada waktu luang, saya akan menggunakannya untuk membaca buku ekonomi

2. Saya berusaha menyelesaikan tugas ekonomi yang diberikan oleh Bapak/Ibu guru tepat waktu

3. Apabila nilai ulangan ekonomi saya jelek, maka saya berusaha memperbaikinya pada waktu ulangan berikutnya

4. Bila saya mengalami kesulitan dalam mengerjakan tugas ekonomi, maka saya akan bertanya pada teman yang lebih tahu.

5. Kalau tidak masuk sekolah, saya tidak menanyakan kepada teman pelajaran dan tugas ekonomi yang diberikan oleh Bapak/Ibu guru.

6. Saya berkeinginan untuk menjadi siswa yang paling pandai pelajaran ekonomi

7. Saya berusaha untuk menyenangi pelajaran ekonomi di sekolah

8. Bila ada tugas kelompok ekonomi saya mengandalkan teman-teman yang lain untuk mengerjakannya.

9. Saya menyukai pelajaran ekonomi sehingga saya akan belajar keras untuk memperoleh nilai yang baik.

10. Tugas ekonomi yang diberikan oleh Bapak/Ibu guru tidak menarik, maka saya tidak mengerjakannya dengan baik
11. Saya mengajak teman di samping saya bercakap-cakap saat pelajaran ekonomi berlangsung.

12. Saya senang membuat keributan dikelas pada saat pelajaran ekonomi berlangsung.

\section{b. Instrumen Lingkungan Sosial}

1. Bapak, ibu dan kakak, mencarikan jalan keluar apabila saya menemui kesulitan dalam belajar ekonomi

2. Bapak, ibu menanyakan hasil ulangan ekonomi saya.

3. Bapak, ibu memberikan nasihat agar saya belajar dengan tekun

4. Bapak, ibu memberikan nasihat agar saya belajar dengan tekun

5. Bapak, ibu menempatkan biaya keperluan sekolah sebagai prioritas daripada pembiayaan keperluan yang lain.

6. Kebiasaan merokok anak-anak di kampung (sekitar tempat tinggal yang sebaya dengan saya)

7. Teman-teman di sekitar tempat tinggal saya menghargai teman yang masih sekolah

8. Masyarakat di lingkungan tempat tinggal saya, peduli terhadap jam belajar

9. Saya begadang malam di kampung bersama masyarakat

10. Saya menggunakan media elektronik atau media cetak dalam belajar

\section{c. Instrumen Sikap Belajar}

1. Materi ekonomi cukup memadai sebagai bekal hidup dimasyarakat.

2. Mata pelajaran ekonomi penting untuk dipelajari siswa SMA

3. Keberhasilan hidup dalam masyarakat tidak tergantung pada penguasaan mata pelajaran Ekonomi

4. Saya senang belajar mata pelajaran ekonomi

5. Saya tertarik dengan hal-hal yang berhubungan dengan Ekonomi

6. Ekonomi merupakan mata pelajaran yang membosankan

7. Pada waktu guru mengajar pelajaran ekonomi, saya kurang memperhatikan

8. Jika ada ulangan, maka saya lebih mempersiapkan diri belajar ekonomi daripada yang lain

9. Jika ada ulangan, maka saya lebih mempersiapkan diri belajar ekonomi daripada yang lain 